\title{
Bir Grup Yetişkinde Çocukluk Dönemi Örselenme Yaşantılarının Çeşitli Değişkenler Açısından İncelenmesi
}

\author{
Investigation of Adults' Childhood Traumas in Terms of Some Variables
}

\section{Makbule KALI SOYER ${ }^{[1]}$ Alperen ŞENOL ${ }^{[2]}$ Kevser Burcu ÇALIK TÜMERDEM[3]}

Başvuru Tarihi:20 Mayıs 2021

Kabul Tarihi:18 Haziran 2021

Bu araștırmanın amacı, yetişkin bireylerin çocukluk çağı ihmal ve istismara maruz kalma sıklığını ve bu bireylerde görülen duygusal ve davranıșsal problemleri incelemektir. Araştırma, nicel araştırma desenlerinden tarama modeli kullanılarak gerçekleștirilmiştir. Katılımcılar uygun örnekleme tekniğiyle ulaşılmış 618 yetişkinden oluşmuştur; katılımcıların \%76.2'si kadın, \%23.8'i erkek ve \% $34.1^{\prime}$ i evli ve yaş ortalaması $28.37 \pm 8,04$ 'dır. Verilerin toplanmasında araştırmacılar tarafından geliştirilmiş olan Kişisel bilgi formu ve Çocukluk Çağı Örselenme Ölçeği veri toplama aracı olarak kullanılmıştır. Araştırma sonucunda, katılımcıların \%90.8'inin fiziksel, \%88.8'inin duygusal ve \%17.7'sinin cinsel istismara farklı derecelerde maruz bırakıldıkları, erkek katılımcıların kadın katılımcılardan anlamlı bir şekilde daha fazla fiziksel ihmal/istismara maruz bırakıldıkları bulgulanmıștır. Cinsel istismar açısından ise cinsiyete dayalı bir fark gözlenmemiştir. Bulgular, eğitim düzeyinin düşük olmasının daha yüksek çocukluk çağı örselenmeleriyle ilișkili olduğunu işaret etmektedir. Duygusal ihmal ve istismar ile fiziksel istismar boyutlarında eğitim düzeyine yönelik istatistiksel farklar belirmektedir. Benzer şekilde, sosyo-ekonomik gelir düzeyi düşük olan grubun daha fazla çocukluk çağı istismarı yaşadığı sonucuna ulaşılmıştır. Çalışmada, psikolojik destek alma geçmişi olanlar diğerlerine göre istatistiksel olarak daha yüksek örselenme ve istismar yaşantısına maruz bırakılmıştır. Düzenli ilaç kullanan ve süreğen hastalığı bulunan bireylerin çocukluk istismar yaşantıları daha fazladır. Son olarak bir veya birden fazla bağımlılık yapıcı madde kullanan bireyler, çocukluk örselenmeleri ve diğer üç alt boyuttaki istismar yaşama açısından risk grubunda olduğu bulgulanmış ve sonuçlar literatür temelinde tartışılmıștır. Ulaşılan bu bulgular konunun önemini göstermekte olup nitel çalışmalarla konunun irdelenmesi önemli görülmektedir.

Anahtar Kelimeler: çocukluk travması, istismar, ihmal, yetişkin, kötü muamele

\section{Received Date:20 May 2021}

Accepted Date:18 June 2021

The aim of this research is to examine the frequency of exposure to childhood neglect and abuse in adults and the emotional and behavioral problems seen in these individuals. Survey method was used from quantitative research designs. Participants consisted of 618 adults who has exposed abuse reached by convenient sampling technique; $76.2 \%$ of the participants were women, $23.8 \%$ were men, $34.1 \%$ of them were married. The average age of the participants was $28,37 \pm 8,04$. As a data collection tool, the Personal Information Form and Childhood Trauma Scale were used. The results are as follows: $90.8 \%$ of the participants stated that they were exposed to various degrees of physical abuse, $88.8 \%$ of them were emotional abuse and $17.7 \%$ of them were sexual abuse. It was concluded that male participants were exposed significantly more physical neglect / abuse than females. Exposure to sexual abuse did not differ in terms of gender. Findings indicate that low education level is associated with more childhood traumatic experiences. There are statistical differences in terms of education level in the dimensions of emotional neglect and abuse and physical abuse. Similarly, it can be said that low socio-economic level is a risk factor for more childhood traumas than others. In this current study, those with a history of receiving psychological support were exposed to a statistically higher childhood traumatic experience than the others. Individuals who use medicine regularly and have chronic diseases have more childhood trauma experiences. Finally, individuals using one or more addictive substances were found to be in the risk group in terms of childhood traumatic experiences and abuse in the other three sub-dimensions, and the results were discussed on the basis of the literature. These findings show the importance of the subject and it is considered important to examine the subject with qualitative studies. Keywords: childhood trauma, abuse, neglect, adult, maltreatment 


\section{GíRiş}

oplumların güçlü ve istikrarlı bir şekilde geleceğe hazırlanmasında, çocukların her yönden sağlıklı yetişmesinin önemi büyüktür. Bu süreçte ebeveynler ya da bakım

1 verenler farkında olmadan ya da kasıtlı bir şekilde çocukların gelişimlerini olumsuz yönde etkileyebilecek ve/veya çocukları örseleyici çeşitli davranışlar sergileyebilmektedir. Örselenme, bireyin ruhsal ve bedensel varlığını çok değişik biçimlerde sarsan, inciten, yaralayan her türlü durum için kullanılmaktadır. Bunlar arasında cinsel saldırıya uğrama, cinsel istismar veya cinsel kötüye kullanma/istismar; dayak, işkence gibi fiziksel kötüye kullanma/istismar; yoksun bırakma, kısıtlama, ihmal etme gibi duygusal kötüye kullanma/istismar vb. gibi çocuğun gelişimini engelleyen ya da kısıtlayan birçok durum, örselenme veya travmatik deneyim olarak sayılabilir (Kozcu, 1989; Öztürk ve Uluşahin, 2015). Çeşitli şekillerde travmaya maruz bırakılan kişinin nasıl ve ne derece etkileneceği olayın türü, sıklığı ve şiddetine, kişinin kalıtsal ve kişilik özellikleri ile gelişimsel özelliklerine göre değişebilmektedir. İlgili olay veya durum bir yetişkin için kolay atlatılabilir gibi görülse, bir çocuk için baş edilmesi güç bir durum halinde yaşanabilir. Çocukların istismar edilmeleri yoluyla örselenmeleri onların sosyal, duygusal, fiziksel ve tüm diğer gelişimsel özelliklerini ve potansiyellerini açığa çıkarmalarında engelleyici bir rol oynayacağı ve bu yaşantıların etkisinin uzun süreli olacağı açıtır (Ludy-Dobson ve Perry 2010; UNICEF, 2016; van der Kolk, 2005).

Çocukların çeşitli şekillerde istismar edilerek örselenmeleri çağımızın önemli sorunlarından biridir. Dünya Sağlık Örgütü (World Health Organisation [WHO], 2017)'nün genç yetişkinler üzerinde yaptığı araştırmada 18 yaş ve öncesinde şiddete maruz kalma durumları sorgulanmıştır. WHO'nun küresel istismar raporuna göre, katılımcılardan \%23'ü fiziksel istismara, \%16'sı fiziksel ihmale, \%36'sı duygusal istismara ve kızların \%18'i, erkeklerin \%8'i cinsel istismara maruz kaldıklarını ifade etmişlerdir. Çocukluk döneminde özellikle cinsel istismarın cinsiyet ayırımı yapmadan kişilerin ruh sağlığı üzerinde diğer istismar edilme durumlarına göre travma sonrası stres bozukluğu ve intihara sürükleme gibi daha olumsuz etkiye sahip olduğu yönünde araştırma bulguları mevcuttur (Afifi ve MacMillan, 2011; Bonanno, 2004; Chelf ve Ellis, 2002; Steenkamp ve ark., 2012). Yetişkinler üzerinde yapılan bir çok çalışmada kişilerin çocukluk döneminde istismar edilme oranının oldukça yüksek oldğu (Anders ve ark., 2012) ve çoğunlukla genel olarak erkeklerin daha fazla istismar edildiği (Aslan ve Alparslan, 1999; Aydın ve İşmen, 2003; Bilim, 2012; Zeren, Yengil, Çelikel, Arık ve Arslan, 2012) yönünde bulgulara ulaşılmıştır. Çocuğun istismarı (cinsel, fiziksel veya duygusal) veya ihmali sadece çocukluk dönemindeki etkisiyle kalmamakta, tüm yaşamı boyunca ruh sağlığı üzerinde olumsuz etkisini sürdürmektedir. Yapılan çalışmalarda, çocukluk çağı istismarının yetişkinlik döneminde depresyona (Aslan, 2015; Lee ve Song, 2017; Mall ve ark., 2018; Vranceanu ve ark., 
2007) kadınlarda doğum sonrası depresyona (Schury ve ark., 2017), travma sonrası stres bozukluğu ve diğer kaygı bozukluklarına (Chelf ve Ellis, 2002; Şahin-Demirkapı, 2014; Vranceanu ve ark., 2007), alkol, madde bağımlılığ sorunlarına (Chasan, 2010; Dube ve ark., 2006; Evren ve ark., 2011; Şahiner, 2012) fiziksel sorunlara, öfke sorunlarına, suça eğilim, şiddete eğilim, yaşam kalitesinde ve akademik başarıda düşüşe (Afifi ve MacMillan, 2011; Anders ve ark., 2012; Kıray, 2018; Rosenberg ve Krugman, 1991; Schore, 2003) ve diğer çeşitli ruhsal problemlere (Anders ve ark., 2012; Chelf ve Ellis, 2002; Kıray, 2018; Rosenberg ve Krugman, 1991; Savi-Çakar, 2018; Şahin-Demirkapı, 2014) neden olduğu yönünde bulgular mevcuttur. Bu araştırmanın problem cümlesi "çocukluk dönemi istismara maruz kalmak yetişkin hayatta çeşitli duygusal ve davranışsal problemlere neden olmakta mıdır? şeklinde düzenlenmiştir. Çocukluk çağı istismarın etkilerine yönelik araştırma bulguları göz önüne alındığında, bu konunun hem bilimsel çalışmalara konu olmaya devam edeceği hem de ulaşılan bulgular açısından yeni çalışmalara kaynaklık edeceği görülmektedir.

\section{Araştırmanın amacı}

Bu araştırmanın amacı, yetişkin bireylerin çocukluk çağı ihmal ve istismara maruz kalma sıklığını ve bu bireylerde görülen duygusal ve davranışsal problemleri incelemektir. Araştırmanın amacı doğrultusunda aşağıdaki sorulara cevap aranmıştır;

1. Yetişkinlerin çocukluk döneminde ihmal ve istismara maruz kalma sıklıkları nedir?

2. Yetişkinlerin çocukluk dönemi ihmal ve istismar edilme düzeyleri kişisel değişkenlere göre (cinsiyet, eğitim düzeyi, algılanan sosyoekonomik düzey) farklılık göstermekte midir?

3. Yetişkinlerin çocukluk dönemi ihmal ve istismar edilme düzeyleri yaşadıkları psikolojik (psikolojik destek alıp almama) ve psikosomatik (süreğen bir hastalık yakınması ve süreğen ilaç kullanımı) problemlerine göre farklılık göstermekte midir?

4. Yetişkinlerin çocukluk dönemi ihmal ve istismar edilme düzeyleri davranışsal (sigara, alkol ve madde kullanımı) problemlerine göre farklılık göstermekte midir?

\section{Araştırmanın önemi}

Yapılan çalışmalarda çocukluk döneminde istismar edilmenin yaygın etkileri olduğuna yönelik bulgular söz konusudur. Ancak, her ne kadar çocukluk dönemi ihmal ve istismarın kişilerin ruh sağlığı üzerinde etkisinin olduğu tartışmasız kabul edilmiş olsa da kişiden ve çevreden kaynaklı olarak bu tür yaşantıların etkisi kişiden kişiye farklılık göstermektedir. $\mathrm{Bu}$ 
açıdan, yetişkinlerin çocukluk döneminde hangi sıklıkta ve ne tür istismara maruz kaldıklarını bilmek, çocukların sağlıklı gelişimleri için önlem alma ve onları koruma açısından önem arz etmektedir. Bozgun ve Pekdoğan (2018) tarafından öğretmen adayları üzerinde yapılan bir araştırmada katılımcıların çocukluk döneminde sırasıyla en sık duygusal ihmal, fiziksel ihmal, cinsel istismar ve fiziksel istismar yoluyla örselendikleri bulgusuna ulaşılmıştır. Cinsiyet açısından bakıldığında çalışmalarda farklı sonuçlar elde edilmiştir. Kıray (2018)'ın çalışmasında erkek yetişkinlerin çocukluk döneminde her yönüyle kadınlara göre daha fazla istismar edilme yoluyla örselendikleri, benzer bir șekilde başka çalıșmalarda cinsel istismar dişında erkeklerin fiziksel ve duygusal olarak kızlardan daha fazla istismar edildiği (Bozgun ve Pekdoğan, 2018; Erükçü, 2013) tespit edilmiştir. Yine, düşük sosyo-ekonomik ortamda büyüyenlerin cinsel istismar dışındaki diğer istismar türlerine daha fazla maruz bırakıldıkları (Bozgun ve Pekdoğan, 2018; Yurteri, 2011), buna karşın bir başka çalışmada (Erükçü, 2013) ise sosyo ekonomik durumun göstergesi olarak her gelir ve eğitim düzeyinde çocukların istismar edilme oranının benzer olduğu şeklinde sonuçlara ulaşılmıştır.

Çocukluk döneminde kişilerin istismar ve ihmali ve bu durumun onların yetişkinlik hayatı boyunca ruhsal sorunlar açısından olumsuz etkileri (Horwitz ve ark., 2001) göz önüne alındığında sorunun ciddiyeti de açığa çıkmaktadır. Bu konuda yapılacak çalışmalar ve ulaşılan bulgular olayın açığa çıkarılmasının yanında, çocuğun korunmasına dair politika yapıcılara ve insana yardım hizmeti veren meslek elemanlarına bilgi sağlaması açısından önem arzetmektedir.

\section{YÖNTEM}

\section{Araştırmanın Modeli}

$\mathrm{Bu}$ çalışma, kesitsel tarama modelinde tasarlanmıştır. Tarama modeli yaşanmış ya da yaşanmakta olan bir durumun olduğu şekliyle tanımlanmasıdır (Karasar, 2009). Araştırmanın katılımcıları olasılık temelli olmayan örnekleme türlerinden uygun örnekleme tekniği ile oluşturulmuştur.

\section{Çalışma Grubu}

Çalışma grubunu, uygun örnekleme tekniği ile ulaşılmış, araştırmaya katılmakta gönüllü toplam 618 yetişkin oluşturmuştur. Uygun örnekleme tekniğinde araştırmanın katılımcıları ulaşılması kolay, araştırma için uygun ve katılıma gönüllü olan kişiler arasından seçilir (Koç Başaran, 2017). Çalışmaya dahil edilen 618 katılımcının \%76.2'si (n=471) kadın, \%23.8'i $(n=147)$ erkek, \%34.1'i (n=211) evli, \%3.8'i (n=23) ilköğretim, \%10.0'u (n=62) orta öğretim ve \%86.2'si (Nr=533) lisans ve daha üstü eğitim düzeyindedir. Çalışma grubunun algıladığı sosyoekonomik düzey incelendiğine; \%6,1'i $(n=38)$ kendilerini düşük, \%85,4'ü $(n r=528)$ orta ve 
\%8,3'ü (n=52) yüksek sosyo-ekonomik düzeye sahip olarak ifade etmişlerdir. Katılımclların, \%13,8'i (n=74) süreğen bir hastalığı olduğunu, \%12'si (n=74) sürekli olarak bir ilaç kullandığını, \%19.9'u ( $\mathrm{Nn}=123)$ hayatının bir döneminde psikolojik yardım aldığını ifade etmektedir. Katılımclların \%43,2'si (nr=267) sigara, alkol ya da keyif verici maddelerden en az birini veya birden fazla maddeyi birlikte kullandığını ifade etmiştir. Katılımcıların yaş ortalaması $28,37 \pm 8,04$ 'dir.

\section{Veri Toplama Araçları}

Kişisel bilgi formu. Yazarlar tarafından oluşturulan kişisel bilgi formu, cinsiyet, eğitim düzeyi, algılanan sosyoekonomik düzey, psikolojik destek alma durumu, süreğen hastalık, sürekli kullandığı bir ilaç, sigara, alkol ya da madde kullanımı değişkenlerini içermektedir.

Çocukluk Örselenme Yaşantıları Ölçeği (ÇÖYÖ). Bernstein ve arkadaşları (1994) tarafından geliştirilen Çocukluk Örselenme Yaşantıları Ölçeği (ÇÖYÖ) 69 maddelik 5'li likert tipinde bir öz bildirim ölçeği olarak düzenlenmiştir. Ölçeğin amacı kişilerin 18 yaş altı dönemdeki örselenme yaşantılarını belirlemektir. Orijinal ölçeğin alt boyutlarının Cronbach alfa katsayıları 0.79-0.94 arasında değişmektedir. Ölçeğin Türkçe’ye uyarlama çalışması Aslan ve Alparslan (1999) tarafından yapılmıştır. İstatistiksel geçerliliğini test etmek için yapılan faktör analizi sonrasında maddeler arası korelasyonu ve faktör yükü düşük olan toplam 29 madde çıkarılmış ve 40 maddelik Türkçe form oluşturulmuştur. Yapılan faktör analizi doğrultusunda ölçeğin, duygusal istismar ve duygusal ihmal (Dİ-DİH), fiziksel istismar (Fİ) ve cinsel istismar (Cİ) şeklinde üç faktörlü bir yapıya sahip olduğu belirlenmiş ve bu faktörlerin toplam varyansın \%62.4'ünü açıkladığı bulunmuştur. Ölçekten alınabilecek en düşük puan 40 en yüksek puan ise 200'dür. Ölçekten alınan yüksek puanlar çocukluk örselenme yaşantılarının sıklığını belirtmektedir. Ölçekte duygusal kötüye kullanım ve duygusal ihmal alt ölçeği için alınabilecek en düşük ve en yüksek puanlar 19-95, fiziksel kötüye kullanım alt ölçeği için 16-80, cinsel kötüye kullanım alt ölçeği içinse 5- 25'dir.Ölçekte ters puanlama yapılan maddeler şunlardır: 4, 7, 8, 10, $12,13,15,19,22,23,26,28,32,35,38,40$. Araştırmacılar, güvenirlik çalışması kapsamında ise cronbach alfa iç tutarlık katsayılarının fiziksel istismar için .94, duygusal istismar ve ihmal için 0.95 ve cinsel istismar için .94 olduğunu ölçeğin genelinde ise .96 olduğunu tespit etmişlerdir.

\section{Veri Toplama Süreci}

Araştırmanın verilerini toplamak için öncelikle uygulanacak ölçme aracı için ölçeği geliştiren ikinci yazardan izin alınmıştır. Takiben alanyazın incelenmiş ve araştırmanın amacı belirlenerek veri toplamak için etik kurula başvurulmuştur. Etik kurul onayı alındıktan sonra araştırmacılar ve meslektaşlarının desteği ile çeşitli sertifika ve gelişim kurslarına devam etmakte olan ve lisans ve üstü eğitim almakta olan yetişkinlere veri seti online olarak whatsapp 
eklentisi ve E-Mail eklentisi olarak gönderilmiştir. Veri seti gönderilmeden önce araștırmanın amacı katılımcılarla paylaşılmış ve katılımın gönüllülüğe dayalı olduğu önemle belirtilmiştir. Geri dönen veri setleri tek tek incelenmiş ve eksiksiz doldurulmuş olan 618 veri seti analize alınmıştır.

\section{Verilerin Analizi}

Verilerin analizinde önce normallik testlerinden Kolmogorov-Smirnov yapılmış ve verilerin normal dağılım göstermemesi ve değişkenlere yönelik grup dağılım sayısındaki nicel dengesizlikten dolayı analizler parametrik olmayan tekniklerle gerçekleştirilmiştir. Analizlerde, ikili karşılaştırmalarda Mann-Whitney U testi, çoklu karşılaştırmalarda ise Kruskal-Wallis H testi kullanılmış ve hata payı .05 olarak alınmıştır.

\section{Araştırmanın Etik Onayı}

Bu araştırma, Marmara Üniversitesi Eğitim Bilimleri Enstitüsü Araştırma ve Yayın Etik Kurulu tarafindan 19 haziran 2020 tarihinde 2020-6-4 onay sayısı ve 2020/30 protokol numarası ile onaylanmıştır.

\section{BULGULAR VE YORUM}

İstatistiki olarak istismara yönelik yapılan sıklık analizi sonrasında, katılımcıların \%94.6'sı çocukluk döneminde herhangi bir tür istismara maruz kaldığını ifade etmişlerdir. \%90.8'i fiziksel, \%88.8'i duygusal ve \%17.7'si cinsel istismara çeşitli derecelerde maruz kaldığını ifade etmişlerdir. Katılımcıların ÇÖYÖ ölçeğinden aldıkları puanların aritmetik ortalaması (X) 63.89 olarak bulgulanmıştır. Dİ-DİH alt ölçeği puan ortalaması $\bar{X}: 35.21 \pm 11.46$, Fİ puan ortalaması X $: 23.09 \pm 7.38$ ve Cİ puan ortalaması $\overline{\mathrm{X}}: 5.60 \pm 1.79$ olarak bulunmuştur.

\section{Tablo 1}

Cinsiyet değişkenine göre ÇÖYÖ puanları Mann Whitney U testi sonucu

\begin{tabular}{|c|c|c|c|c|c|c|c|}
\hline & Değişken & $\mathbf{N}$ & $\mathrm{X}_{\text {Sira }}$ & $\sum$ sira & $\mathbf{U}$ & $\mathbf{z}$ & p \\
\hline \multirow{2}{*}{ ÇÖYÖ TOP. } & Kadın & 471 & 299.81 & 141211.0 & \multirow{2}{*}{30055.0} & \multirow{2}{*}{-2.42} & \multirow{2}{*}{$.02 *$} \\
\hline & Erkek & 147 & 340.54 & 50060.0 & & & \\
\hline \multirow{2}{*}{ Dİ-DİH } & Kadın & 471 & 302.26 & 142366.5 & \multirow{2}{*}{31210.5} & \multirow{2}{*}{-1.81} & \multirow{2}{*}{.07} \\
\hline & Erkek & 147 & 332.69 & 48904.5 & & & \\
\hline \multirow{2}{*}{ Fìi } & Kadın & 471 & 297.44 & 140095.0 & \multirow{2}{*}{28939.0} & \multirow{2}{*}{-3.01} & \multirow{2}{*}{$.000^{* *}$} \\
\hline & Erkek & 147 & 348.14 & 51176.0 & & & \\
\hline \multirow{2}{*}{ Cí } & Kadın & 471 & 308.69 & 145393.5 & \multirow{2}{*}{34237.5} & \multirow{2}{*}{-0.31} & \multirow[b]{2}{*}{.76} \\
\hline & Erkek & 147 & 312.09 & 45877.5 & & & \\
\hline
\end{tabular}
${ }^{*} \mathrm{p}<.05,{ }^{* *} \mathrm{p}<.001$

Bireylerin bu araştırmada cinsiyete göre çocukluk örselenme yaşantıları puanı ile erkek $(X=340.54)$ ve kadın ( $X=299.81)$ sıra ortalamaları puanları arasında istatistiksel olarak erkek katılımcıların lehine anlamlı bir fark bulunmuştur $(U=30055.0, \quad p<0.05)$. Bu fark erkek katılımcıların çocukluk çağı örselenmeye daha fazla maruz kaldığı anlamına gelmektedir. 
Duygusal istismar ve ihmal açısından erkeklerin sıra ortalaması ( $X=332.69)$ puanları kadınların ortalamasına ( $X=302.26)$ göre daha yüksek olmasına rağmen aradaki bu farklılık istatistiksel olarak anlamlı değildir ( $\mathrm{U}=31210.5$, p>0.05). Erkek katılımcıların fiziksel istismar ortalaması ( $X=348.14)$ ile kadınların sıra ortalaması (X=297.44) puanları arasında istatistiksel olarak anlamlı fark bulunmuştur $(U=28939.0, p<0.05)$. Cinsel istismar açısından ise kadın ( $X=308.69)$ ve erkek katılımcıların sıra ortalamaları $(\mathrm{x}=312.09)$ arasında istatistiksel olarak manidar bir fark bulunmamıștır ( $\mathrm{U}=34237.5$, $\mathrm{p}>0.05)$.

\section{Tablo 2}

Eğitim ve algılanan sosyo-ekonomik düzeye göre ÇÖYÖ puanlarına yönelik yapılan Kruskal Wallis$H$ testi sonuçları

\begin{tabular}{|c|c|c|c|c|c|c|c|}
\hline & & Gruplar & $\mathbf{N}$ & $\mathbf{X}_{\text {sira }}$ & $\mathrm{X}^{2}$ & Sd & $\mathbf{P}$ \\
\hline \multirow{12}{*}{ 㺼 } & \multirow{3}{*}{ ÇÖYÖ TOP. } & İlköğretim & 23 & 369.63 & & & \\
\hline & & Ortaöğretim & 62 & 368.06 & 10.76 & 2 & $.005^{*}$ \\
\hline & & Lisans/üstü & 533 & 300.09 & & & \\
\hline & \multirow{3}{*}{ Dİ-DİH } & İlköğretim & 23 & 373.65 & & & \\
\hline & & Ortaöğretim & 62 & 368.44 & 11.30 & 2 & $.004^{*}$ \\
\hline & & Lisans/üstü & 533 & 299.88 & & & \\
\hline & \multirow{3}{*}{ Fi } & İlköğretim & 23 & 361.07 & & & \\
\hline & & Ortaöğretim & 62 & 394.55 & 9.11 & 2 & $.01^{*}$ \\
\hline & & Lisans/üstü & 533 & 300.87 & & & \\
\hline & \multirow{3}{*}{ CI } & İlköğretim & 23 & 294.78 & & & \\
\hline & & Ortaöğretim & 62 & 315.27 & .505 & 2 & .77 \\
\hline & & Lisans/üstü & 533 & 309.46 & & & \\
\hline \multirow{12}{*}{ 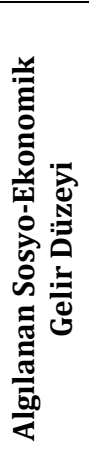 } & \multirow{3}{*}{ ÇÖYÖ TOP. } & Düşük & 38 & 360.24 & & & \\
\hline & & Orta & 529 & 311.75 & 10.55 & 2 & $.005^{*}$ \\
\hline & & Yüksek & 51 & 241.95 & & & \\
\hline & \multirow{3}{*}{ Dİ-DİH } & Düşük & 38 & 363.84 & & & \\
\hline & & Orta & 529 & 312.51 & 13.41 & 2 & $.001^{* *}$ \\
\hline & & Yüksek & 51 & 231.75 & & & \\
\hline & \multirow{3}{*}{ ÇÖYÖ-Fİ } & Düşük & 38 & 357.00 & & & \\
\hline & & Orta & 529 & 310.48 & 7.02 & 2 & $.03^{*}$ \\
\hline & & Yüksek & 51 & 257.92 & & & \\
\hline & \multirow{3}{*}{ ÇÖYÖ-CI } & Düşük & 38 & 313.72 & & & \\
\hline & & Orta & 529 & 309.45 & .32 & 2 & .85 \\
\hline & & Yüksek & 51 & 300.77 & & & \\
\hline
\end{tabular}

Tablo 2. incelendiğinde, lisans ve daha yüksek eğitim düzeyine sahip katılımcıların ÇÖYÖ toplam puan sıra ortalamaları istatistiksel olarak anlamlı bir şekilde daha düşük çıkmıştır $\left(\mathrm{x}^{2}(2)\right.$ $=10.76, \mathrm{p}<0.05)$. Bu fark ortaöğretim düzeyinde eğitimli olanların lehinedir $(U=12884.5$, $\mathrm{p}<0.001$ ). Yine, eğitim düzeyine göre duygusal istismar ve ihmal puan sıra ortalamaları arasında anlamlı fark çıkmış $\left(\mathrm{x}_{(2)}^{2}=11.30, \mathrm{p}<0.05\right)$ ve bu farka göre ortaöğretim düzeyinde eğitimli olanların lisans ve üstü düzeyde eğitimli olanlara göre daha fazla duygusal istismar ve ihmale maruz bırakıldığı tespit edilmiştir $(\mathrm{U}=12844.5, \mathrm{p}<0.05)$. Yine, ortaöğretim düzeyinde eğitimli olanların lisans ve üstü düzeyde eğitimli olanlara göre fiziksel olarak daha fazla istismara maruz bırakıldığı bulgulanmıștır ( $\mathrm{U}=13127.5, \mathrm{p}<0.05)$. Eğitim düzeyine göre cinsel istismara maruz 
bırakılma yaşantılarına yönelik puan ortalamalarının gruplara göre istatistiksel olarak farklılaşmadığı bulgulanmıștır $\left(x^{2}(2)=0.505, p>0.05\right)$.

Bireylerin algılanan sosyo-ekonomik gelir durumlarına göre, sosyo-ekonomik gelir düzeyi yüksek olanların ÇÖYÖ puan ortalamaları, diğer grupların puan ortalamalarından daha düşük çlkmıştır $\left(\mathrm{x}^{2}{ }_{(2)}=10.55, \mathrm{p}<0.05\right)$. Gözlenen bu farklılık, sosyo-ekonomik gelir düzeyi düşük olanlar ile sosyo-ekonomik düzeyini yüksek algılayan gruplar arasında $(U=632.0, p<0.05)$ ve sosyo-ekonomik düzeyi orta olanlar ile yüksek gruplar arasında $(U=10381.5, p<0.05)$ istatistiksel olarak manidardır. ÇÖYÖ alt boyutları incelendiğinde, bireylerin sosyo-ekonomik durumlarına göre duygusal istismar ve ihmal yaşantılarının, sosyoekonomik gelir düzeyi yüksek olanların ÇÖYÖ puanları diğer gruplarından istatistiksel olarak manidar şekilde daha düşük çıkmıştır $\left(\mathrm{x}^{2}(2)=1.41, \mathrm{p}<0.05\right)$. Gözlenen bu farklılık sosyo-ekonomik gelir düzeyini düşük algılayanlar ile yüksek algılayanlar arasında $(U=591.0, p<0.05)$ ve sosyo-ekonomik gelir düzeyini orta düzeyde algllayanlar ile yüksek algllayanlar arasında $(U=9902.5, p<0.05)$ istatistiksel olarak manidardır. Benzer şekilde, araştırmada bireylerin sosyo-ekonomik durumlarına göre fiziksel istismar yaşantılarının, sosyoekonomik düzeyi yüksek olanların Fİ puan ortalamaları diğer sosyo-ekonomik düzeydeki gruplarından istatistiksel olarak manidar olarak $\left(\mathrm{x}^{2}{ }_{(2)}=7.02\right.$, p<0.05) daha düşük çıkmıștır $(X=257.92)$. Gözlenen bu farklılık sosyo-ekonomik düzeyi düşük olanlarla sosyo-ekonomik gelir düzeyi yüksek gruplar arasında $(U=674.0, p<0.05)$ ve sosyoekonomik gelir düzeyini orta seviyede algılayanlarla yüksek olarak algllayanlar arasında (U= 11154.0, p<0.05) istatistiksel olarak manidardır. Katılımcıların ÇÖYÖ-Cİ puanlarının sosyoekonomik durumuna göre farklılaşmadığı bulgulanmıştır $\left(\mathrm{x}^{2}{ }_{(2)}=0.32, \mathrm{p}>0.05\right)$.

\section{Tablo 3}

Psikolojik destek alma, düzenli olarak ilaç kullanma, fiziksel rahatsızlı ve madde kullanmaya yönelik ÇÖYÖ puanlarına dair Man Whitney U testi sonuçları

\begin{tabular}{|c|c|c|c|c|c|c|c|c|}
\hline & Değişken & & $\mathbf{N}$ & $\mathrm{X}_{\text {Sira }}$ & $\sum$ Sira & $\mathbf{U}$ & $\mathbf{z}$ & $\mathbf{P}$ \\
\hline \multirow{8}{*}{ 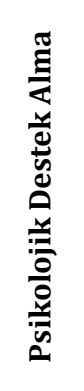 } & \multirow{2}{*}{ ÇÖYÖ-TOP. } & Evet & 123 & 359.41 & 44207.5 & \multirow{2}{*}{24303.5} & \multirow{2}{*}{-3.47} & \multirow{2}{*}{$.001^{* *}$} \\
\hline & & Hayır & 495 & 297.10 & 147063.5 & & & \\
\hline & \multirow{2}{*}{ Dİ-DİH } & Evet & 123 & 356.76 & 43881.5 & \multirow{2}{*}{24629.5} & \multirow{2}{*}{-3.28} & \multirow{2}{*}{$.000^{* * *}$} \\
\hline & & Hayır & 495 & 297.76 & 147549.5 & & & \\
\hline & \multirow{2}{*}{ Fİ } & Evet & 123 & 355.46 & 43722.0 & \multirow{2}{*}{24789.0} & \multirow{2}{*}{-3.20} & \multirow{2}{*}{$.001^{* *}$} \\
\hline & & Hayır & 495 & 298.08 & 147549.0 & & & \\
\hline & \multirow{2}{*}{ Cí. } & Evet & 123 & 330.50 & 40651.5 & \multirow{2}{*}{27859.5} & \multirow{2}{*}{-2.20} & \multirow{2}{*}{$.03^{*}$} \\
\hline & & Hayır & 495 & 304.28 & 150619.5 & & & \\
\hline \multirow{6}{*}{ 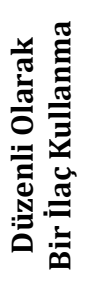 } & \multirow{2}{*}{ ÇÖYÖ-TOP. } & Evet & 74 & 373.64 & 27649.0 & \multirow{2}{*}{15382.0} & \multirow{2}{*}{-3.3} & \multirow{2}{*}{$.000^{* * *}$} \\
\hline & & Hayır & 544 & 300.78 & 163622.0 & & & \\
\hline & \multirow{2}{*}{ Dİ-DİH } & Evet & 74 & 379.32 & 28069.5 & \multirow{2}{*}{14961.5} & \multirow{2}{*}{-3.60} & \multirow{2}{*}{$.001^{* *}$} \\
\hline & & Hayır & 544 & 300.00 & 163201.5 & & & \\
\hline & \multirow{2}{*}{ Fí } & Evet & 74 & 352.12 & 26057.0 & \multirow{2}{*}{16974.0} & \multirow{2}{*}{-1.45} & \multirow{2}{*}{$.03^{*}$} \\
\hline & & Hayır & 544 & 303.70 & 165201.5 & & & \\
\hline
\end{tabular}




\begin{tabular}{|c|c|c|c|c|c|c|c|c|}
\hline & Cí & $\begin{array}{l}\text { Evet } \\
\text { Hayır }\end{array}$ & $\begin{array}{l}74 \\
544\end{array}$ & $\begin{array}{l}328.14 \\
306.97\end{array}$ & $\begin{array}{l}24282.0 \\
166989.0\end{array}$ & 18749.0 & -1.45 & .15 \\
\hline \multirow{8}{*}{ 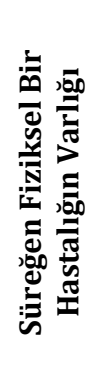 } & \multirow{2}{*}{ ÇÖYÖ-TOP. } & Var & 85 & 361.74 & 30748.0 & \multirow{2}{*}{18212.0} & \multirow{2}{*}{-2.91} & \multirow{2}{*}{$.000^{* * *}$} \\
\hline & & Yok & 533 & 301.17 & 160523.0 & & & \\
\hline & \multirow{2}{*}{ Dİ-DİH } & Var & 85 & 364.31 & 30966.0 & \multirow{2}{*}{17994.0} & \multirow{2}{*}{-3.05} & \multirow{2}{*}{$.001^{* *}$} \\
\hline & & Yok & 533 & 300.76 & 160305.0 & & & \\
\hline & \multirow{2}{*}{ FİI } & Var & 85 & 351.03 & 29837.5 & \multirow{2}{*}{19122.5} & \multirow{2}{*}{-2.32} & \multirow{2}{*}{$.02 *$} \\
\hline & & Yok & 533 & 302.88 & 161433.5 & & & \\
\hline & \multirow{2}{*}{ Ci } & Var & 85 & 332.28 & 28244.0 & \multirow{2}{*}{20716.0} & \multirow{2}{*}{-1.92} & \multirow{2}{*}{.60} \\
\hline & & Yok & 533 & 305.87 & 163027.0 & & & \\
\hline \multirow{8}{*}{ 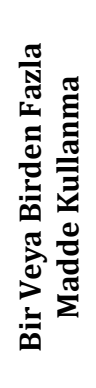 } & \multirow{2}{*}{ ÇÖYÖ-TOP. } & Evet & 267 & 333.99 & 89175.5 & \multirow{2}{*}{40319.5} & \multirow{2}{*}{-2.96} & \multirow{2}{*}{$.003^{*}$} \\
\hline & & Hayır & 351 & 290.87 & 102095.5 & & & \\
\hline & \multirow{2}{*}{ Dİ-DİH } & Evet & 267 & 328.19 & 87626.0 & \multirow{2}{*}{41869.0} & \multirow{2}{*}{-2.72} & \multirow{2}{*}{$.02 *$} \\
\hline & & Hayır & 351 & 265.28 & 103645.0 & & & \\
\hline & \multirow{2}{*}{ Fí } & Evet & 267 & 339.12 & 90545.5 & \multirow{2}{*}{38949.5} & \multirow{2}{*}{-3.61} & \multirow{2}{*}{$.000^{* * *}$} \\
\hline & & Hayır & 351 & 286.97 & 100725.5 & & & \\
\hline & \multirow{2}{*}{ Ci } & Evet & 267 & 326.44 & 87160.0 & \multirow{2}{*}{42535.0} & \multirow{2}{*}{-3.11} & \multirow{2}{*}{$.002 *$} \\
\hline & & Hayır & 351 & 296.61 & 104111.0 & & & \\
\hline
\end{tabular}

Tablo 3. incelendiğinde, katılımcılardan yaşantılarının herhangi bir döneminde psikolojik destek alanların ÇÖYÖ puanı sıra ortalaması $(X=359.41)$, psikolojik destek almayanların ortalamasına (X=297.10) göre anlamlı bir şekilde daha yüksek bulunmuştur $(\mathrm{U}=24303.5, \mathrm{p}<0.05)$. Alt boyutlar incelendiğinde, psikolojik destek alanların ortalaması $(X=356.76)$, psikolojik destek almayanların ortalamasına $(X=297.76)$ göre anlamlı şekilde daha yüksek olduğu görülmüştür ( $U=24629.5, p<0.05)$. Aynı şekilde, hayatlarının bir döneminde psikolojik destek alanların sıra ortalaması (X=355.46), psikolojik destek almayanların ortalamasına $(X=298,08)$ göre anlamlı bir şekilde daha yüksek bulunmuştur $(U=24789.0$, $\mathrm{p}<0.05)$. Katılımcılardan psikolojik destek aldığını ifade edenlerin cinsel istismar puan ortalamasının ( $X=330.50)$, psikolojik destek almayanların ortalamasına $(X=304,28)$ göre anlamlı şekilde daha yüksek olduğu görülmüştür (U=27859.5, p<0.05).

ÇÖYÖ-Dİ-DİH puanları incelendiğinde katılımcılardan sürekli olarak bir ilaç kullanmakta olanların sıra ortalaması $(X=379.32)$ ile sürekli olarak ilaç kullanmayanların ortalaması $(X=300,00)$ arasında $(U=14961.5, p<0.05)$ ve sürekli ilaç kullananların fiziksel istismar puanları sıra ortalaması ( $X=352.12)$ ile sürekli olarak ilaç kullanmayanların sıra ortalamaları $(X=303.70)$ arasında istatistiksel olarak anlamlı fark bulunmuştur (U=16974.0, $p<0.05)$. Sürekli ilaç kullanan ve kullanmayanların cinsel istismar puanları sıra ortalaması arasında ise anlamlı bir fark bulunmamıştır $(\mathrm{U}=18749.0, \mathrm{p}>0.05)$.

Katılımcılardan süreğen bir hastalığa sahip olanların ÇÖYÖ puan ortalaması (X=361.74), süreğen hastalığı olmayanların ortalamasına göre (X=301.17) anlamlı bir şekilde daha yüksek 
çıkmıştır (U=18212.0, p<0.05). Alt boyutlar incelendiğinde, süreğen bir hastalığa sahip olanların duygusal istismar puan sıra ortalaması $(X=364.31)$, süreğen hastalığı olmayanlara $(X=300.76)$ göre $(U=17994.0, p<0.05)$ ve fiziksel istismar puanları sıra ortalaması $(X=351.03)$, süreğen hastalığı olmayanların ortalamasına $(X=302.88)$ göre $(U=19122.5, \mathrm{p}<0.05)$ istatistiksel olarak anlamlı farklılık gösterdiği bulgusuna ulaşılmıştır. Süreğen bir hastalığa sahip olanlar ile olmayanların cinsel istismar sıra puan ortalamaları arasında anlamlı bir farklılık gözlenmemiştir $(\mathrm{U}=20716.0, \mathrm{p}>0.05)$.

Katılımclların bir ya da daha fazla keyif verici madde ve/veya alkol kullanma veya kullanmama durumuna göre Dİ-DİH, Fİ VE Cİ alt ölçekleri puan sıra ortalamaları arasında istatistiksel olarak anlamlı fark çıkmıştır. Bir ya da daha fazla keyif verici madde ve/veya alkol kullananların duygusal istismar puanı sira ortalaması (X=328.19) kullanmayanların ortalamasına ( $X=265.28)$ göre $(U=41869.0, p<0.05)$, fiziksel istismar puanları sıra ortalaması $(X=339.12)$ kullanmayanların ortalamasina $(X=286.97)$ göre $(U=38949.5, \quad p<0.05)$, cinsel istismar puanları sıra ortalaması $(X=326.44)$ ile herhangi bir madde kullanmayanların ortalamasına (X=296.61) göre istatistiksel olarak anlamlı düzeyde daha yüksek bulunmuştur $(\mathrm{U}=42535.0, \mathrm{p}>0.05)$.

\section{TARTIŞMA, SONUÇ VE ÖNERÍLER}

Bu araştırmanın amacı, yetişkin bireylerin çocukluk çağı ihmal ve istismara maruz kalma sıklığını ve bu bireylerde görülen duygusal ve davranışsal problemleri incelemektir. Bu amaç doğrultusunda yapılan analizler sonucunda katılımcıların \%90,8'i fiziksel, \%88,8'i duygusal ve \%17,7'si cinsel istismara çeşitli derecelerde maruz bırakıldıklarını ifade etmişlerdir. Bulunan bu sonuçlar ürkütücü şekilde yüksektir. Alanda konu ile ilgili sıklıkla çalışmalar yürütülmektedir ancak, ülkemizde yapılan çalışmalara bakıldığında çocukluk çağında kötü muameleye, istismara maruz bırakıldığını ifade edenlerin oranının yıllar içinde artığı görülmektedir. Evren ve ark. (2011)'ın araştırmasına katılanların \%63.5'i en az bir çeşit çocukluk çağı istismar yaşantısının olduğunu belirtmişlerdir. Şen (2019) ile Bozgun ve Pekdoğan (2018)'ın araştırmalarında katılımcıların ihmal ve istismara uğrama sıklığı en çok duygusal ihmal ve takiben fiziksel ihmal, duygusal istismar, cinsel istismar ve fiziksel istismar olarak sıralanmıştır. Zoroğlu ve ark. (2001) tarafından gerçekleştirilen araştırmanın bulgularına göre, katılımcıların \%34.8'i çocukluk döneminde travmatik yaşantıya maruz bırakıldıklarını ifade etmişlerdir; travmaya maruz kalanların \%20.5'i bir tür travmaya, \%8.7'i iki tür travmaya ve \%5.6'sı farklı üç ya da daha çok travmaya maruz kaldıklarını ifade etmişlerdir; bunlardan ihmal en sık bildirilen (\%16.5) ruhsal travmadır. Bunu sıklık açısından duygusal (\%15.9), fiziksel (\%13.5), cinsel (\%10.7) istismar (ensest dahil) takip etmektedir. Ülkemizde yapılan bu araștırmada katılımcıların \%34.8'i herhangi bir travmaya maruz kaldığını ifade ederken, Almanya'da yapılan geniş çaplı bir 
araştırmada katılımcıların sadece \%16 sının duygusal, fiziksel, cinsel istismar, duygusal ve fiziksel ihmali kapsayan çocukluk çağı travması kriterlerine maruz kaldığını belirlenmiştir (Beutel ve ark., 2017). WHO (2017)'nun yaptığı araștırma sonucunda hazırladığı küresel istismar raporuna göre ise katılımcılardan \%23 ü fiziksel istismar, \%16'sı fiziksel ihmal, \%36'sı duygusal istismara maruz kaldıkları rapor edilmiştir.

Katılımcıların cinsiyete göre istismara maruz bırakılma durumlarının karşılaştırıldığı analizlerde duygusal ve cinsel istismara maruz bırakılma, cinsiyete göre farklılaşmadığı halde erkek katılımcıların kadın katılımcılardan anlamlı bir şekilde daha fazla fiziksel ihmal/istismara maruz kaldıkları sonucuna ulaşılmıştır. Alanyazın incelendiğinde, cinsiyete göre istismar boyutlarına yönelik yapılan çalışma sonuçlarının farklılık gösterdiği tespit edilmiştir. Bazı çalışmalarda çocukluk çağı travmalarının kadın ve erkekler üzerinde uzun süreli etkileri bağlamında herhangi bir farklılaşma belirlenmemişken (Çakar, 2018), yine bir başka çalışmada duygusal istismara maruz kalmanın cinsiyet açısından farklılık göstermediği bulgulanmıştır (Kanak ve Arslan, 2018). Benzer şekilde, cinsiyetler arasında çocukluk çağı örselenme yaşantılarına göre fark olmadığını (Aydın, 2018; Bostancı ve ark., 2006; Örsel ve ark., 2011) bulgulayan birçok çalışma alanyazında yer almaktadır. Bozgun ve Pekdoğan (2018)'ın çalışmasında ise cinsel istismar dışında erkeklerin anlamlı bir şekilde daha fazla fiziksel ve duygusal ihmal ve istismara maruz kaldıkları bulgulanmıştır. Bununla birlikte, Erükçü (2013)'nün araştırmasında erkeklerin daha fazla fiziksel ve cinsel istismara maruz kaldığı bulgulanmıştır. Birçok çalışmada ise cinsel istismar da dahil tüm ihmal ve istismar alanlarına erkeklerin daha fazla maruz kaldıkları bulgulanmıştır (Aslan ve Alparslan, 1999; Aydın ve İşmen, 2003; Bilim, 2012; Kıray, 2018; Zeren ve ark., 2012; Yöyen, 2017). Buna karşın WHO (2017)'nun küresel istismar raporunda ise kızların $\% 18$ 'i, erkeklerin \%8'inin cinsel istismara maruz bırakıldıkları bulgulanarak genelde kızların daha fazla cinsel istismara maruz kaldığı sonucuna ulaşılmıştır. Benzer şekilde alanda yapılan diğer birçok çalışmada, kadınların erkeklere göre çocukluk çağında daha fazla cinsel istismar yaşantısına maruz kaldıklarına yönelik sonuçlara ulaşılmıştır (Aktepe, 2009; Aydın, 2018; Kara ve ark., 2004; Ovayolu ve ark., 2007; Scher ve ark., 2003; Topbaş, 2004; Walrath ark., 2003). Ressell ve ark. (2018) yaptığı çalışmada çocukluğunda cinsel olarak istismara maruz bırakılan bireylerin sıklıkla fiziksel ihmal başta olmak üzere diğer istismar türlerine de maruz bırakıldığı bulgulanmıştır. Yine, Beutel ve ark. (2017)'nın yaptıkları çalışmada bu araştırma ve ülkemizde yapılan bazı araştırma bulgularından farklı olarak kadın katılımcıların erkeklere göre iki kat daha fazla cinsel istismara maruz kaldıkları, kadın ve erkeklerin benzer şekilde çocukluklarında fiziksel ve duygusal olarak ihmal edildikleri sonucuna varmışlardır. Yapılan bazı çalışmalarda ise yetişkinlik evresine göre istismar öyküsünün değiştiği bulgulanmıştır; yetişkin katılımcılarda Fiziksel ihmal/istismar, genç yetişkin 
katılımcılarda ise duygusal ihmal/ istismar daha yüksek çıkmıştır (Aydın ve İşmen, 2003; Beutel ve ark., 2017).

Araştırma bulgularından biri de katılımcıların eğitim düzeyine ve sosyo-ekonomik gelir düzeyine göre çocukluk travmalarının incelenmesidir. Analizler sonucunda, lise ve daha düşük düzeyde eğitimli olanların yüksek öğrenim düzeyinde eğitimli olan katılımcılara göre ve sosyoekonomik gelir düzeylerini düşük ve orta düzeyde algılayan katılımcıların, yüksek algllayanlara göre daha fazla duygusal ve fiziksel istismar maruz kaldıkları bulgusuna ulaşılmıştır. Yapılan bir çok araştırmada (Aydın ve İşmen, 2003; Beutel vd., 2017; Bozgun ve Pekdoğan, 2018; Yurteri, 2011) araştırmamızın bulgularını destekler nitelikte çocukluk travması yaşayanların yaşamayanlara oranla daha düşük gelir seviyesine sahip, lise diploması olmayan düşük eğitim düzeyindeki kişiler olduğu bulgusuna ulaşılmıştır. Yoksul ve düşük eğitim düzeyine sahip ortamlarda büyüyen çocuklar birçok açıdan dezavantajlı çocuklardır. Bu dezavantajın etkisinin yetişkinlik döneminde de sürdügü ve düşük eğitimli ve düşük sosyo-ekonomik gelir düzeyine sahip katılımcıların daha fazla istismar ve ihmal öyküsüne sahip oldukları görülmektedir. Araştırma sonucunda çlkan bu fark, düşük ekonomik statü ve eğitim düzeyine sahip olan ebeveynlerin çocuk yetiştirme konusundaki hem yeterli bilgiye sahip olmamalarından hem de içinde bulundukları ortamda gördükleri davranış kalıplarını sergileme eğiliminde oluşlarından kaynaklanıyor olabilir. Ancak, alanyazın incelendiğinde, cinsel istismara maruz bırakılmak ile eğitim düzeyi ve sosyo-ekonomik düzeyin bağlantısı kesin olarak tespit edilememiş ve her sosyo-ekonomik grupta da görülebileceği yönünde bulguya ulaşmış çalışmalar da mevcuttur (Erükçü, 2013; Hedin, 2000). Yine, bu araştırma bulgusundan farklı olarak Erükçü (2013)'nün araştırmasında sosyo-ekonomik gelir düzeyi yüksek ailelerde çocuğun cinsel olarak daha fazla istismar edildiği bulgulanmıştır.

Analizler sonucunda, yaşamlarının herhangi bir döneminde veya halen psikolojik destek almakta olan katılımcıların, psikolojik destek almayan katılımcılara göre daha fazla duygusal, fiziksel ve cinsel olarak istismar edildikleri bulgusu elde edilmiştir. Kişilerin psikolojik desteğe ihtiyaç duymuş olması ruhsal sağlı problemi yaşadıkları anlamını taşımaktadır. Şen (2019) yaptığı çalışmada psikolojik desteğe ihtiyaç duymayı önemli görmüş ve psikolojik destek alan kadınların cinsel istismar ölçeğinden aldığı puanların, psikolojik destek alan erkeklerin cinsel istismar ölçeğinden aldığı puanlardan daha yüksek olduğu görülmüştür. Lee ve ark. (2018) yaptığı araştırmada halihazırda ruhsal sağlık sorunu olanların, özellikle şizofren hastalarının, çocukluk döneminde çok fazla istismar edildikleri bulgusunu elde etmiştir. Ayrıca, çocukluk travması öyküsü olan ve bugün kendilerini sağlıklı olarak ifade eden katılımcıların da ruhsal sorunlar açısından risk taşıdığı söylenebilir. Nitekim, Çakar (2018)'ın yaptığı çalışmada çocukluk çağı travmaları ile yetişkin psikolojik semptomları (belirtileri) arasında belirgin ve olumlu ilişki 
saptanmıştır. Sheikh ve ark. (2016) ise yaptıkları araștırma sonucunda duygusal istismarın fiziksel istismara oranla ruhsal sağlıksızlık ile anlamlı şekilde ilişkili olduğu sonucunu elde etmişlerdir. Yine, benzer bir șekilde, Zoroğlu ve ark. (2001)'nın araştırmasında, maruz kalınan travma türü sayısı arttıkça kişilerin hem kendine fiziksel zarar verme davranışında ve özkıyım girişiminde hem de dissosiyasyon skorlarında çok ileri seviyede anlamlı bir artış olduğu sonucunu elde etmişlerdir. Yapılan çalışmalar, çocukluk travmaları ile ruhsal sağlığın bozulma belirtileri arasındaki ilişkiye dikkat çekmektedir (Anders ve ark., 2012; Chelf ve Ellis, 2002; Kıray, 2018; Rosenberg ve Krugman, 1991; Şahin-Demirkapı, 2014). Fakat bazı çalışmalarda ise, ruhsal anlamda bir hastalık olmasa bile çocukluk döneminde istismar edilmenin kişilerin mutluluk gibi olumlu psikolojik işlevlerindeki düşüşe vurgu yapmaktadır. Bunlardan biri olan Barnum ve Perrone-McGovern (2017)'ın yaptıkları araştırmada, çocuklukta yoğun cinsel travma yaşamış üniversite öğrencilerinin düşük öznel iyi oluşa sahip olukları bulgusunu elde etmişlerdir. Bir başka ifade ile bu sonuç, çocukluk çağında cinsel olarak istismar edilmenin yetişkinlik döneminde kişilerin daha fazla olumsuz duygular yaşadıklarını göstermektedir. Benzer şekilde yapılan birçok çalışmada da, travmatik yaşam deneyimi ve olumsuz duygular arasında ilişkiyı sıklıkla vurgulamaktadır (Şenol, 2021; Wu, Zhao ve Chao, 2020; Zheng ve ark., 2021). Kong (2018)'un yaptığı araştırmada, çocukluk çağında duygusal ve fiziksel istismara uğramak yetişkinlikte öznel iyi oluşu olumsuz etkilediği yani bu kişilerin daha fazla olumsuz duygular yaşadıkları ancak, bu istismar eğer anne aracılığıyla yapılmışsa bu durumun kişilerin öznel iyi oluşlarını etkilemediği tespit edilmiştir.

Yapılan analizler sonucunda, düzenli olarak bir ilaç kullandığını ifade eden katılımcılar ve halihazırda fiziksel olarak sağlık sorunu yaşadığını ifade eden katılımcıların çocukluk döneminde duygusal ve fiziksel olarak daha fazla istismara maruz kaldıkları bulgulanmıștır. Kişilerin sürekli olarak bir ilaç kullanmaları ruhsal veya ruhsal kaynaklı fiziksel bir sorunları olduğu anlamına gelebilir. Yapılan birçok araştırmada bu araştırma sonucunu destekler şekilde çocukluk döneminde istismar edilmenin kişilerin fiziksel ve ruhsal sağlıkları üzerinde bozulmaya yönelik bir etkisi olduğu bulunmuştur (Kıray, 2018; Lee ve ark., 2018; Sheikh ve ark., 2016). Yine, Beutel ve ark. (2017) yaptıkları araştırmada yetişkinlikteki stres ve somatik belirtilerin, çocukluk travması yaşayanlarda yaşamayanlara oranla, ortalama iki kat daha yüksek oranda gözlendiği saptanmıştır.

$\mathrm{Bu}$ araştırmada katılımcılardan sigara, alkol ve/veya keyif verici maddelerden birini veya birden fazlasını birlikte kullandığını ifade edenlerin bu maddelerden herhangi birini veya birden fazlasını kullanmayanlara göre çocukluk dönemlerinde daha fazla duygusal, fiziksel ve cinsel istismara maruz kaldıkları bulgusuna ulaşılmıştır. Araştırma bulgularını destekler nitelikte çocukluk çağında istismara maruz bırakılanların sigara, alkol ve/veya madde kullanma gibi 
davranışsal sorunlar yaşadıklarını yönelik başka araştırma bulguları mevcuttur (Chasan, 2010; Sheikh ve ark., 2016; Şahiner, 2012). Ancak, Chasan (2010)'ın araştırmasında cinsel istismar ile alkol bağımlılığı arasında manidar bir ilişki bulunamamıștır. Buna karşın, Evren ve Ögel (2003)'in araştırmasında ise çocukluk dönemi fiziksel ve cinsel istismar edilme yetişkinlikte alkol ve madde kullanma ile ilişkili bulunmuştur. Benzer şekilde, Evren ve ark. (2011)'nin alkol bağımlısı erkek katılımcılar üzerinde gerçekleştirdikleri araştırmada çocukluk çağı travmaları ile alkol bağımlılığını ilişkili bulmuşlardır. Bu araștırma bulgusu ve diğer araștırma bulguları çocukluk travmaları ile davranışsal problemler arasında bir ilişki olduğunu gösterir niteliktedir. $\mathrm{Bu}$ durumun, çocukluk dönemi istismara maruz kalanlar açısından istismara dair bir bilişsel kaçış veya başetme yolu olarak yaşandığı düşünülebilir.

$\mathrm{Bu}$ araştırma bazı sınırlıklar içermektedir. Araştırma bulgularına bakıldığında yıllar içinde ülkemizde çocukluk döneminde istismar edilme oranında artış gözlenmektedir. Bu sonuç belki de örnekleme tekniğinden ve/veya örneklem sayısından kaynaklanıyor olabilir. İleride farklı örneklem grupları üzerinden ve nitel yöntemlerle desteklenmiş çalışmalarla konunun incelenmesi yarar sağlayacaktır. Özellikle Milli Eğitim Bakanlığı ve Aile ve Sosyal Hizmetler Bakanlığı'nın da desteğiyle daha geniş kitlelere ulaşılarak bir çalışmanın yapılması konuyu daha gerçekçi değerlendirmeye olanak sağlayacaktır. Aynı şekilde, konunun önemi göz önüne alınarak bu bulgular doğrultusunda çocuğun bakımı konusunda önleyici nitelikte aile ve ana-baba eğitimleri düzenlenmesi uygun olacaktır.

Yurtiçinde ve yurtdışında yapılan birçok çalışmada çocukluk döneminde kadınların daha fazla cinsel istismara maruz kaldığı bulgulanmıştır (WHO, 2017). Bu araştırmada cinsel istismara maruz kalmanın cinsiyete göre farklılaşmadığı bulunmuştur. Bu sonucun kültürel bir farktan mı kaynaklandığı araştırmaya değer bir konu olarak gelecek çalışmalar için bir öneri olabilir.

Psikolojik kaynaklı olan somatik yakınmalar ile çocukluk çağı travması arasında bir ilişki olduğuna yönelik araştırma bulguları mevcuttur (Şenol, 2021), bu ilişkiyi açığa çıkarıcı laboratuvar ölçümleriyle ve muayene bulguları ile eşleștirilmiş geriye dönük kapsamlı araştırmalar yapılması önerilebilir. Yine, gelecekte çocukluk travmasının yetişkinlikteki etkilerinin inceleneceği araştırmaların hem nicel hem nitel araştırma yöntemlerinin birlikte kullanılacağı yöntemlerin tercih edilmesi ve bu yolla maruz kalınan travmanın ve türünün ayrıntılı olarak incelenmesi önerilir. 


\section{KAYNAKÇA}

Afifi, T. O., \& McMillan, H. L. (2011). Resilience followind child maltreatment: A review of protective factors. Canadian Journal of Psychiatry, 56(5), 266-272. https://doi.org/10.1177/070674371105600505

Aktepe, E. (2009). Çocukluk çağı cinsel istismarı. Psikiyatride Güncel Yaklaşımlar, 1(2), 95-119.

Anders, S. L., Frazier, P. A., \& Shallcross, S. L. (2012). Prevalence and effects of life event exposure among undergraduate and community college students. Journal Of Counseling Psychology, 59(3), 449-457. https://doi.org/ 10.1037/a0027753

Arslan, G. (2015) Relationship between childhood psychological maltreatment, resilience, depression and negative self-concept. Yeni Symposium, 53(4), 3-9. https://doi.org/10.5455/nys.20160328090400

Aslan, S. H., \& Alparslan, Z.N. (1999). "Çocukluk Örselenme Yaşantıları Ölçeği'nin Bir Üniversite Öğrencisi Örnekleminde Geçerlik, Güvenirlik ve Faktör Yapısı”. Türk Psikiyatri Dergisi, $10(4), 275-285$.

Aydın, E. (2018). Çocukluk çağı travmalarının psikolojik sağlamlık ve depresyon belirtileri üzerine etkisi [Yayımlanmamış yüksek lisans tezi]. Fatih Sultan Mehmet Vakıf Üniversitesi.

Aydin, O., \& Ismen, A. E. (2003). 18-25 yas grubu erkeklerde çocukluk çagi örselenme yasantisinin incelenmesi. MÜ Atatürk Egitim Fakültesi Egitim Bilimleri Dergisi, 18, 7-20.

Barnum, E. L. ve Perrone- McGovern, K. (2017). Attachment, Self-Esteem and Subjective WellBeing Among Survivors of Childhood Sexual Trauma. Journal of Mental Health Counseling, 39 (1), 39-55. https://doi.org/10.17744/mehc.39.1.04

Beutel, M. E., Tibubos, A. N., Klein, E. M., Schmutzer, G., Reiner, I., Kocalevent, R.D., \& Braehler, E. (2017). Childhood adversities and distress - The role of resilience in a representative sample. PLoS ONE, 12 (3). https://doi.org/ 10.1371/journal.pone.0173826

Bonanno, G. A. (2013). How prevalent is resilience following sexual assault?: Comment on Steenkamp et al. (2012). Journal of Traumatic Stress, 26(3), 392-393.

Bozgun, K., \& Pekdoğan, S. (2018). Öğretmen adaylarının çocukluk dönemi örselenme yaşantılarının bazı değişkenler açısından incelenmesi. Elektronik Sosyal Bilimler Dergisi, 17(67), 982-996.

Bostancı, N., Albayrak, B., \& Bakoğlu, İ. (2006). Üniversite öğrencilerinde çocukluk çağı travmalarının depresif belirtileri üzerine etkisi. New Symposium Journal, 44(2): 189- 195.

Chasan, N. (2010). Alkol bağımlılığı ile çocukluk çağı travmaları ilişkisi [Yayımlanmamış yüksek lisans tezi]. Maltepe Üniversitesi.

Chelf, C. M., \& Ellis, J. B. (2002). Young adults who were sexually abused: demographics as predictors of their coping behaviors. Child Abuse and Neglect, 26, 313-316. https://doi.org/10.1016/s0145-2134(01)00327-1

Çakar, F. S.(2018). Yetişkinlerin Çocukluk Çağı Travmatik yaşantıları ile psikolojik belirtileri arasındaki ilişkide yılmazlığın ve cinsiyetin rolü. Pamukkale Üniversitesi Eğitim Fakültesi Dergisi, 44, 114-131.

Demirkapı, E. Ş. (2014). Çocukluk çağı travmalarının duygu düzenleme ve kimlik gelişimine etkisi ve bunların psikopatolojiler ile ilişkisi [Yayımlanmamış yüksek lisans tezi]. Adnan Menderes Üniversitesi.

Dube, S. R., Miller, J. W., Brown, D. W., Giles, W. H., Felitti, V. J., Dong, M., \& Anda, R. F. (2006). Adverse childhood experiences and the association with ever using alcohol and initiating alcohol use during adolescence. Journal of Adolescent Health, 38(4), 444-452. https://doi.org/10.1016/j.jadohealth.2005.06.006 
Erükçü, G. (2013). Farklı sosyo-ekonomk düzeyden gelen ergenlerin çocukluk dönemi örselenme yaşantılarının bazı değişkenler açısından incelenmesi [Yayımlanmamış yüksek lisans tezi]. Hacettepe Üniversitesi.

Evren, C., Dalbudak, E., \& Evren, B. (2011). Childhood trauma and quality of life among alcohol dependent men. Anatolian Journal of Psychiatry, 12, 245-252.

Hedin, L. W. (2000). Physical And Sexual Abuse Against Women And Children. Current Opinion içinde; Obstetrics \& Gynecology, 12(5), 349- 355.

Horwitz, A. V, Widom, C.S., McLaughlin, J., \& White, H. R. (2001). The impact of childhood abuse and neglect on adult mental health: a prospective study. Journal of Health and Social Behavior, 42(2), 184-201.

Kanak, M., \& Arslan, AD. (2018). A Study of the Relationship Between the Level of Emotional Abuse Perceived by High School Students and their Levels of Psychological Resilience. Sakarya University Journal of Education, 8 (2), 187-201. https://doi.org/10.19126/suje.373618

Kara, B., Biçer, Ü., \& Gökalp, A. (2004); “Çocuk İstismarı”, Çocuk Hastalıkları Ve Sağlığı Dergisi, 47(2): 140-151.

Karasar, N. (2009). Araştırmalarda Rapor Hazırlama. Ankara: Nobel Yayınevi.

Kıray, P. (2018). Çocukluk çağı travmaları, algılanan sosyal destek ve algılanan anne baba tutumunun psikolojik sağlık ile arasındaki ilişski [Yayımlanmamış yüksek lisans tezi]. Üsküdar Üniversitesi.

Koç Başaran, Y. (2017). Sosyal Bilimlerde Örnekleme Kuramı. ASOS Journal, 5(47), 480-495. https://doi.org/10.16992/ASOS.12368

Kong, J. (2018). Childhood Maltreatment and Psychological Well-Being in Later Life: The Mediating Effect of Contemporary Relationships with the Abusive Parent. Journals of Gerontology: Social Sciences, 73 (5), 39-48. https://doi.org/10.1093/geronb/gbx039

Kozcu, Ș. (1989). Çocuk istismarı ve ihmali. Ege Üniversitesi. Psikoloji Seminer, 6(7), 63-76

Lee, E. E., Sirkin Martin, A., Tu, X., Palmer, B. W., \& Jeste, D. V. (2018). Childhood Adversity and Schizophrenia: The Protective Role of Resilience in Mental and PhysicaL Health, and Metabolic Markers. Journal of Clinical Psychiatry, 79 (3). https://doi.org/10.4088/JCP.17m11776

Lee, M-A., \& Song, R. (2017) Childhood abuse, personality traits and depressive symptoms in adulthood. Child Abuse and Neglect, 65, 194-203.

Ludy-Dobson, C. R., \& Perry, B. D. (2010). The role of healthy relational interactions in buffering the impact of childhood trauma. Working with children to heal interpersonal trauma: The power of play, 26-43.

Mall, S., Mortier, P., Taljaard, L., Ross, J., Stein, D. J., \& Lochner, C. (2018) The relationship between childhood adversity, recent stressors, and depression in collage students attending a South African University. BMC Psychiaty, 18(63), 3-10.

Ovayolu N, Uçan Ö, Serindağ S. 2007 Çocuklarda Cinsel İstismar ve Etkileri. Firat Sağllk Hizmetleri Dergisi; 4:14-22.

Ressell, M., Lyons, J., \& Romano, E. (2018). Abuse characteristics, multiple victimisationand resilience among young adult males with histories of childhood sexual abuse. Child Abuse Review, 27, 239-253. https://doi.org/10.1002/car.2508

Rosenberg, D. A., \& Krugman, R. D. (1991). Epidemiology and outcome of child abuse. Annuel Review Medicine,42, 217-224.

Sheikh, M. A., Abelsen, B., \& Olsen, J. A. (2016). Clarifying Associations between Childhood Adversity, Social Support, Behavioral Factors, and Mental Health, Health, and Well-Being 
in Adulthood: APopulation-Based Study. Frontiers in Psychology, 7 (246), 727. https://doi.org/10.3389/fpsyg.2016.00727

Schore, A. (2003). Early relational trauma, disorganized attachment, and the development of a predisposition to violence. M. F. Solomon \& D. J. Siegel (Ed.), Healing trauma: Attachment, mind, body, and brain içinde. New York: Norton Company.

Schury, K., Zimmermann, J., Umlauft, M., Hulbert, A. L., Guendel, H., Ziegenhain, U., \& Kolassa, I.-T. (2017). Childhood maltreatment, postnatal distress and the protective role of social support. Child Abuse \& Neglect, 67, 228-239. https://doi.org/10.1016/j.chiabu.2017.02.021

Şen, M. (2019). Psikolojik destek alan ve almayan bireylerde çocukluk çağı travmaları ve dürtüsellik ilişkisinin incelenmesi [Yayımlanmamış yüksek lisans tezi]. Maltepe Üniversitesi.

Şenol, A. (2021). Travma sonrası bilişler ile somatizasyon arasında duyguların aracı rolü [Yayımlanmamış yüksek lisans tezi]. Marmara Üniversitesi.

Topbaş, M. (2004). İnsanlığın Büyük Bir Ayıbı: Çocuk İstismarı. TSK Koruyucu Hekimlik Bülteni, $3(4), 76-80$.

UNICEF (2016). The State of the World's Children. New York.

Van der Kolk, B. (2005). Developmental Trauma Disorder: Toward a rational diagnosis for children with complex trauma histories. Psychiatric Annals, 35(5), 401-408. https://doi.org/10.3928/00485713-20050501-06

Vranceanu, A-M., Hobfoll, S., \& Johnson, R. J. (2007) Child multi-type maltreatment and associated depression and PTSD symptoms: The role of social supports and stress. Child Abuse and Neglect, 31, 71-84. https://doi.org/10.1016/j.chiabu.2006.04.010

Walrath, C., Ybarra, M., Holden, E.W., Liao, Q., Santiago, R., \& Leaf, R. (2003). Children With Reported Histories Of Sexual Abuse Utilizing Multiple Perspectives To Understand Clinical And Psychosocial Profiles. Child Abuse Neglect, 27, 509-524. https://doi.org/10.1016/s0145-2134(03)00035-8

World Health Organisation [WHO] (2017). Child maltreatment. https://www.who.int/violence_injury_prevention/violence/child/Child_maltreatment_i nfographic_EN.pdf?ua=1

Wu, H., Zhao, J., \& Chao, X. (2020). Influence of attributions on negative emotions of individuals experiencing parenting-related trauma. Social Behavior and Personality: an international journal, 48(8), 1-9. https://doi.org/10.2224/sbp.8693

Zeren, C., Yengil, E., Çelikel, A., Arık, A., \& Arslan, M. (2012). Üniversite öğrencilerinde çocukluk çağı istismarı sıklığı. Dicle Tıp Dergisi, 39(4), 536-541.

Zheng, F., Wu, W., Wang, L., Ngoubene-Atioky, A. J., \& Chen, L. (2021). Childhood trauma and suicidal ideation among Chinese female prisoners: The mediating roles of negative emotions and social support. Personality and Individual Differences, 168, 110405. https://doi.org/10.1016/j.paid.2020.110405 


\section{EXTENDED ABSTRACT}

\section{Introduction}

It is clear that traumatizing children through abuse will play an impeding role in revealing their social, emotional, physical and all other developmental characteristics and potentials, and the impact of these experiences will be long-lasting (Ludy-Dobson and Perry 2010; UNICEF, 2016; van der Kolk, 2005). Child abuse (sexual, physical or emotional) or neglect does not only have its effect in childhood, but also continues to have a negative impact on mental health throughout her/his life. Studies have shown that childhood abuse leads to VARİUS mental, psychological, social behavioral, physical and academic problems (Afifi \& MacMillan, 2011; Anders et al., 2012; Aslan, 2015; Chelf and Ellis, 2002; Kıray, 2018; Lee \& Song, 2017; Mall et al., 2018; Schury et al., 2017 ; Rosenberg \& Krugman, 1991; Savi-Çakar, 2018; Schore, 2003; Şahin-Demirkapı, 2014; Şahiner, 2012; Vranceanu et al., 2002). In this respect, knowing how often and what kind of abuse adults are exposed to during childhood is important in terms of taking precautions for the healthy development of today's children and protecting them. The aim of this research is to examine childhood trauma on adults and is there differences in regard to personal variables and the emotional and behavioral problems.

\section{Method}

This study was designed in scanning model. The participants of the research were formed by convenient sampling technique, which is one of the non-probability-based sampling types. Of the 618 participants included in the study, $76.2 \%(\mathrm{Nr}=471)$ were female and $23.8 \%$ $(\mathrm{Nr}=147)$ were male. The mean age of the participants was $28.37 \pm 8.04$. The data of the study were collected through the Childhood Trauma Scale developed by Bernstein et al. (1994) and a personal information form. Ethics committee approval was obtained to conduct the research and participation in the research was based on volunteerism. The Mann-Whitney $U$ test and the Kruskal-Wallis $\mathrm{H}$ test were used in the analysis of the data.

\section{Results}

It was concluded that $94.6 \%$ of the participants participating in the study were exposed to any kind of abuse during their childhood. In the analyzes performed, a statistically significant difference was found between the male ( $X=340.54)$ and female ( $X=299.81)$. It was concluded that men were exposed to physical abuse significantly more than women but there were not differences exposed to emotional neglect and abuse and exposed to sexual abuse in regard to gender. It was found that those with secondary education were exposed to more physical and emotional abuse than those with graduate level and post graduate level and the participants with a low socio-economic level were exposed to emotional and physical abuse more than 
another groups. The CTQ score average of the participants who received psychological support at any time in their lives ( $\mathrm{X}=359.41)$ was found to be significantly higher than the average of those who did not receive psychological support ( $X=297.10)$. Among the participants, those who use drugs constantly and those who have any physical illness have higher physical and emotional abuse scores, but there is no significant difference between their sexual abuse scores.

\section{Discussion and Conclusion}

As a result of the research, the participants stated that they were exposed to various degrees abuse; $90.8 \%$ of physical abuse, $88.8 \%$ emotional abuse and $17.7 \%$ sexual abuse. Similarly, Evren et al. (2011) 63.5\% of the participants and Zoroğlu et al. (2001) concluded that $34.8 \%$ of the participants were exposed to at least one type of childhood abuse. On the other hand, in a study conducted in Germany, this rate is $16 \%$ (Beutel et al., 2017). According to the global abuse report of WHO (2017), 23\% of the participants were exposed to physical abuse, $16 \%$ to physical neglect, $36 \%$ to emotional abuse.

In the analyzes comparing the abuse status of the participants by gender, it was concluded that although emotional and sexual abuse did not differ according to gender, male participants were significantly more exposed to physical neglect/abuse than female participants. When the literature on exposure to childhood abuse was examined, it was observed that different results were obtained; In some studies, it has been determined that the long-term effect of childhood trauma does not differ according to gender (Çakar, 2018; Kanak ve Aslan, 2018). On the other hand, many studies have found that men are more exposed to all kinds of abuse than women (Aslan \& Alparslan, 1999; Aydın \& İşmen, 2003; Bilim, 2012; Kıray, 2018; Zeren et al., 2012; Yöyen, 2017).

As a result of the analysis, it was found that those with secondary or lower education were exposed to more emotional and physical abuse than those with higher education, and the participants who perceived their socio-economic levels as low and moderate were exposed to more emotional and physical abuse. While many research findings (Aydın \& İşmen, 2003; Beutel et al., 2017; Bozgun \& Pekdoğan, 2018; Yurteri, 2011) support the findings of our research, besides, in some studies, it has been concluded that child abuse does not differ according to education and socio-economic level (Erükçü, 2013; Hedin, 2000).

It was found that the participants who were receiving psychological support at any time in their lives or still were abused more emotionally, physically and sexually than were not. Findings in studies showing that there is a relationship between childhood traumas and mental symptoms in the same direction support the result of this research (Anders et al., 2012; Chelf \& Ellis, 2002; Kıray, 2018; Rosenberg \& Krugman, 1991; Şahin-Demirkapı, 2014). 
It was found that participants who stated that they regularly use a medicine and those who stated that they currently have physical health problems were exposed to more emotional and physical abuse during childhood. This result is similar to the findings of many studies in the field ( Beutel and et al., 2017; Kıray, 2018; Lee and et al., 2018; Sheikh and et al., 2016).

It was found that the participants who abused alcohol and substances were exposed to more emotional, physical and sexual abuse during their childhood. There are research findings that support this research findings that those exposed to childhood abuse experience behavioral problems (Chasan, 2010; Sheikh et al., 2016; Şahiner, 2012). 